\title{
DIRECTIVES FOR SHARIA BANKING FINANCIAL PERFORMANCE IN INDONESIA
}

\author{
Uun Sunarsih \\ College of Economics Indonesia (STEI) \\ uun.sunarsih@yahoo.co.id \\ Dede Firmansyah \\ College of Economics Indonesia (STEI) \\ dedefirman24@gmail.com
}

Received: $12-02-2018$

Revised: $12-04-2018$

Accepted: $19-04-2018$

\section{ABSTRACT}

This study aims to analyze the influence of Islamic ethical identity, board of commissioners, audit committee and external audit on the financial performance of sharia banking in Indonesia period 2012-2016 and obtained 7 sample companies. The method used is content analysis. The results showed that only the board of commissioners had an effect on the financial performance, so the bigger the board of commissioners the greater the role in conducting supervision in sharia banking. The identity of Islamic ethics has no effect, this is because investors have different views on company performance measures. The audit committee has no effect because the audit committee can not perform its role to reduce the opportunistic nature of management. External audits have no effect as external audits are unable to ensure that the audit process is in compliance with the procedures so that it is deemed unable to provide high quality audits.

Keywords: Audit Committee; Board of Commissioners; External Audit; Financial Performance; Identity of Islamic Ethics.

\section{ABSTRAK}

Penelitian ini bertujuan untuk menganalisis pengaruh identitas etika Islam, dewan komisaris, komite audit dan audit eksternal terhadap kinerja keuangan perbankan syariah di Indonesia periode 2012-2016 dan memperoleh 7 sampel perusahaan. Metode yang digunakan adalah analisis konten. Hasil penelitian menunjukkan bahwa hanya dewan komisaris yang berpengaruh pada kinerja keuangan, sehingga semakin besar dewan komisaris semakin besar perannya dalam melakukan pengawasan di perbankan syariah. Identitas etika Islam tidak berpengaruh, ini karena investor memiliki pandangan yang berbeda terhadap ukuran kinerja perusahaan. Komite audit tidak berpengaruh karena komite audit tidak dapat menjalankan perannya untuk mengurangi sifat oportunistik manajemen. Audit eksternal tidak berpengaruh karena audit eksternal tidak dapat memastikan bahwa proses audit sesuai dengan prosedur sehingga dianggap tidak dapat memberikan audit berkualitas tinggi.

Kata Kunci: Audit Eksternal; Dewan Komisaris; Komite Audit; Kinerja Keuangan, Identitas Etika Islam.

How to cite: Sunarsih, U., \& Firmansyah, D. (2018). Directives For Sharia Banking Financial Performance In Indonesia. Akrual: Jurnal Akuntansi. 9 (2): 111-128. doi: http://dx.doi.org/10.26740/jaj.v9n2.p111-128

\section{INTRODUCTION}

Company performance is one measure of success in performing corporate financial functions. A good measure of corporate performance begins with the trust of investors to the company that the funds invested in safe 
conditions and is expected to provide a good return. The size of a company's performance appraisal using financial statements is the easiest way to assess management performance. However, performance measures that rely on financial measures are not enough. Anthony \& Govindarajan (2005) emphasize that if a measure of success measured only by financial measures would be dysfunctional. This happens for several reasons, which will encourage shortterm actions that are not in line with the longterm interests of the company. Second, the company unit manager may not take a useful action for the long-term company because it only thinks of short-term profit gain and the third is the pursuit of short-term profit as the sole purpose of the company can distort communication between business unit managers with senior and fourth managers is control tight finance can motivate managers to manipulate data.

The size performance of companies that rely solely on financial perspective has weaknesses and limitations. Therefore, companies, especially banks must have a concept of performance appraisal that is not only seen from the financial side, but also viewed from the side of non-financial. Assessment of Islamic banking performance is not only on profit-taking alone, but how the principles of sharia are enforced in carrying out its operations, including business ethics. Business ethics in a company will be reflected in the values, vision and mission of the company, policies and policy actors (Zaki, et al., 2014). Business ethics run by an organization will be an identity for the organization concerned. In other words, the identity of sharia banking is reflected in all activities undertaken and disclosed in the annual report.

Riel \& Balmer (1997) formulate corporate identity in three main dimensions, namely communication, visual image and behaviour. Purwanto (2006) explains that communication is done in the business world by using various communication media available to deliver business messages to other parties effectively and efficiently, so that the purpose of delivering business messages can be achieved. Visual representation is an effective way to communicate with diverse recipients, and is commonly found in today's business environment (Boove \& Thill, 2002). While organizational behaviour is the study of what people think, feel and do in and around the organization (Wibowo, 2013:2).

The success of sharia banking will be a driving force for other organizations that breathe Islam. Haniffa \& Hudaib (2007) explain that the success of sharia banking is determined by several factors. First, the underlying philosophy and values in the delivery of information on which trust and assurance are based on the stakeholders. Information not only covers the conformity of operational activities with the principles of sharia, but also information that explains that the management of sharia banking is occupied by competent people, understand the 
sharia economic system and in line with the goals of the organization. The second factor is the providers of products and services free usury. The prohibition of usury is clearly stated in the Qur'an and indicates that sharia banks are not allowed to set interest on loans or investments. Furthermore, the third factor is a transaction in accordance with Islamic principles. According to Yaya, et al., (2016:42) a transaction, even though it has used goods or services that are lawful and obtained by the mechanism of obtaining benefits allowed by religion, must also qualify the validity of a contract. The fourth factor is focusing on development and social goals. Sharia banking is expected to be more socially responsible than conventional banking, as it emphasizes social justice. The forms of contribution that can be made by Islamic banks include the management of zakat, alms and qardh hassan funds, employee welfare, concern for debtors and public services and the last is the compliance of the Sharia Supervisory Board (DPS).

Islamic banking has a DPS that plays a role to ensure that every formulation, product and service is in accordance with the principles of sharia and is within the scope of Islamic norms. In other words, DPS acts as an internal control mechanism and its main objective is to provide credibility to the operations of sharia banks by legitimizing the legitimacy of sharia views, thereby enhancing the performance of sharia banking.
Ethical identity in a company is crucial to improve the performance of the company. Financial performance is an analysis conducted to see how far a company has implemented by using the rules of financial implementation properly and correctly (Fahmi, 2014). Research on the ethical identity of the company's financial performance has been done by Berrone, et al., (2007); Sukardi \& Wijaya, (2013) that companies with strong ethical identity will achieve greater stakeholder satisfaction level, which will affect the financial performance. Another factor that affects corporate performance is Corporate Governance (CG). CG is applied to control the company both for internal and external purposes, and based on the prevailing regulations that banks in carrying out their operations shall be guided by the principles of Good Corporate Governance (GCG) (Effendi, 2016). The CG mechanism is divided into two parts: internal and external. Internal mechanisms are carried out by managerial ownership, board size, audit committee, proportion of independent board of commissioners, while external indicator mechanism consists of institutional ownership (Beiner, et al., 2003).

In addition to the disclosure of Islamic ethical identity affecting company performance is the size of the board of commissioners. Board of commissioners is a key element in influencing financial performance (Nopiani, et al., 2015; Widayati, 2013; Sulistyowati \& Fidiana, 2017). The board of commissioners serves to exercise oversight. The board of commissioners is elected 
by shareholders in the General Meeting of Shareholders (AGM) representing the interests of shareholders, thus having an important and decisive role for the success in implementing CG in order to run smoothly as expected (Effendi, 2016). Still according to Nopiani et al., (2015); Widayati (2013) explains that the large number of members of the board of commissioners in a company, the supervision of the board of directors becomes much better, advice and input for the board of directors became more. So that the performance of management becomes better and also impact on the improvement of company performance.

Considering the commissioner's role in supervising the company's progress is quite heavy, the commissioner can be assisted by several committees, one of which is the audit committee (Effendi, 2016). According to the Indonesian Audit Committee (IKAI), the audit committee is a professional and independent working committee established by the board of commissioners. The task of the audit committee is to assist and strengthen the functioning of the board of commissioners in exercising oversight functions over the financial reporting, risk management, audit implementation, and CG implementation processes in companies. Widayati (2013); Merawati \& Hatta (2014) states that the audit committee has an influence on the performance of the company. This proves that the audit committee is responsible for overseeing the financial statements, overseeing external audits, and observing internal control systems (including internal auditing) so as to reduce the opportunistic nature of management cheating in the form of earnings management by overseeing the financial statements and monitoring the audit external. The establishment of an audit committee aims to improve effectiveness in the context of good corporate CG implementation. The establishment of the audit committee should be established through a Decision Letter of the Financial Services Authority Number: Kep-643 / BL / 2012 that the audit committee is a sub-committee of the board of commissioners providing formal communication between the board, internal control system and external auditor.

In addition to the size of the board of commissioners and audit committees that affect financial performance, there are other factors namely external audit (Merawati \& Hatta, 2014). An external auditor is an external examination of a company's financial statements prepared by a particular organization. The purpose of an external audit is to ensure that financial statements are in accordance with the actual conditions without any fraud in it. According to Merawati \& Hatta (2014) external auditor has an important role in creating corporate value and CG implementation, as it is considered more independent than internal audit. One of the main functions of the external auditor is to ensure the proper running of the procedure and to prevent the occurrence of other fraud (Sukrisno in Merawati \& Hatta, 2014). Public accounting firms that fall into the big four category are often 
considered to provide high quality audits. This is evidenced by the results of research Christiani \& Nugrahanti (2014); Merawati \& Hatta (2014) stating that the company's performance measurements as measured by external auditors (big 4) are higher than firms audited by non-big external audits 4.

Research on the identity of Islamic ethics has been widely studied, but shows different results. Therefore researchers are motivated again to conduct similar research by developing research that has been done by Fauziyah \& Siswantoro (2016). The research Fauziyah \& Siswantoro (2016) used the Identity of Islamic Ethics only per theme, while in this study used the whole theme and added three variables namely board of commissioners (Sulistyowati \& Fidiana, 2017), audit committee and external audit of (Merawati \& Hatta, 2014).

Based on this background, the researcher is interested to conduct research by examining the influence of Islamic Ethics Identity Disclosure and Corporate Governance Mechanism towards Shariah Banking Financial Performance in Indonesia year 2012-2016. The purpose of this study is to determine the influence of Ethical Disclosure of Islamic Ethics and Corporate Governance Mechanism on Sharia Banking Financial Performance in Indonesia 2012-2016.

\section{LITERATURE REVIEW}

Corporate identity can be interpreted through three paradigms. First paradigm graphic design that is identical with nomenclature, logo, corporate characteristics and visual identification organization. Second, the integrated communication paradigm that is seen from the way the company communicates effectively. The third is the interdisciplinary paradigm, which is an approach consisting of several mixed elements that form the corporate identity in which corporate identity is seen through behaviour, communication, and through the symbolism that is attributed to internal and external parties (Riel \& Balmer, 1997). While Haniffa \& Hudaib (2007) describes eight dimensions of vision and mission statement; disclosure of the board of directors and management; disclosure of banking products and services; Disclosure of zakat, alms and qardh hassan fund; Disclosure of commitments to employees; commitment to the debtor; commitment to community communities; And the disclosure of the Sharia Supervisory Board with a total of 78 indicators outlined in the five main features of Islamic ethical identity which include the underlying philosophy and values, the provision of products and services of usury free, transactions or agreements that conform to Islamic principles, Development and social objectives, as well as adherence to the Sharia Supervisory Board.

Disclosure of information in the annual report can be divided into two, namely mandatory disclosure and voluntary disclosure. According to Armadi \& Anggraeni, (2010) mandatory disclosure is the required disclosure in the annual report according to the rules of the Copyright @ 2018 AKRUAL: Jurnal Akuntansi 
Financial Services Authority (OJK). While voluntary disclosure is a disclosure that is not required by $\mathrm{OJK}$, in other words disclosure that exceeds what is required. The annual report is a formal communication document that includes quantitative information (financial reports), narratives, photos, and graphs. In addition, this annual report contains the company's history, financial status, and desired development direction (Setyorini, 2007). With annual reports, the company (management) communicates the results of its operations to stakeholders. So if viewed from the perspective of agency theory, the annual report can be considered as a means of management accountability as an agent to stakeholders in general and the owner or principal in particular. According to Statement of Financial Accounting Concepts (SFAC) no. 1, there are two purposes of financial reporting. First, provide useful information to investors, creditors, and other users to make investment decisions, credits, and other decisions. Second, provide information on the cash flow effect to assist investors and creditors in assessing the prospects of the company's net cash flows.

Good Corporate Governance by the World Bank is a collection of laws, regulations, and rules that must be met that can drive the performance of corporate resources to function efficiently in order to generate long-term, sustainable economic value for shareholders and the surrounding community as a whole. Meanwhile, according to the Finance Committee on Corporate Governance (FCCG), it defines corporate governance as the process and structure used to direct and manage the company's business and activities towards improving business growth and corporate accountability. Based on this understanding, Corporate Governance can be defined as a system designed to guide professional management of companies based on the principles of transparency, accountability, responsibility, independence, fairness, and equity. Corporate governance can encourage the formation of clean, transparent, and professional management practices.

The mechanism of corporate governance is a clear procedure and relationship between decision-making parties and those who exercise control or oversight of decisions. Corporate governance mechanism according to Nopiani et al., (2015) is a system capable of controlling and directing the operational activities of the company and the parties involved therein, so it can be used to suppress the occurrence of agency problems. Corporate governance is used to control companies acting for other internal and external interests with respect to their rights and obligations. Good corporate governance mechanism is divided into two parts, namely internal and external. Internal mechanisms are performed by managerial ownership, board size, audit committee, proportion of independent board of commissioners, while external indicator mechanism consists of institutional ownership (Beiner et al., 2003). 
Financial performance is a description of the achievement of the company's success can be interpreted as a result that has been achieved on activities that have been done. Can be explained that the financial performance is an analysis conducted to see how far a company has implemented by using the rules of financial implementation properly and correctly (Fahmi, 2014). Performance can be defined as the measured activity of an entity in a given period as part of the success of the work Masjid \& Cahyono (2015); Sulistyowati \& Fidiana (2017). Meanwhile, according to the Indonesian Institute of Accountants (IAI) (2007) understanding of financial performance is the company's ability to manage and control its resources.

\section{RESEARCH METHODS}

This research is a quantitative research using secondary data of syariah banking in Indonesia. The method used in this research is content analysis. Content analysis is an observational research method used systematically to evaluate the symbol content of all forms of communication recorded Kolbe and Burnett in Sekaran \& Bougie (2010) .The data used in the research are panel data that is the annual report of sharia banking in Indonesia in period observations of 2012-2016 that can be accessed through the website of each sharia banking in Indonesia.

The population in this study are all Sharia Commercial Banks in Indonesia which amounted to 12 Bank Syaiah during the 117 observation period. The sample in this research is chosen by purposive sampling method, which is by fulfilling the specified characteristics (1) the Bank is still operating in the observation period 2012-2016. (2) Has published its annual report on the official website of sharia banks in Indonesia registered in OJK period 2012-2016. (3) A sharia bank that has a positive profit. Based on these criteria, the sample of 7 sharia banks is obtained.

The data obtained by 7 sharia banking then analysed by using classical assumption test and hypothesis test. To test the hypothesis then created a model that explains the relationship between variables to be studied. Model is compiled using panel regression equation as follows:

$$
\begin{aligned}
& \text { ROAit }=\alpha+\beta 1 \text { EIIit }+\beta 2 \text { BOCit }+\beta 3 \\
& \text { KAUDit + } 44 \text { BIG4it + e }
\end{aligned}
$$

Information:

$\begin{array}{ll}\text { ROAit } & \begin{array}{l}\text { : Return On Assets of firm } \mathrm{i} \text { in } \\ \text { period } \mathrm{t}\end{array} \\ \alpha & : \text { The coefficient of the constant } \\ \text { B1 - } \beta 4 & : \text { Regression coefficient of } \\ & \text { independent variables } \\ \text { EIIit } & : \text { Ethical Identity Index of } \\ & \text { company } \mathrm{i} \text { in period } \mathrm{t} \\ \text { BOCit } & : \text { The size of the Board of } \\ & \text { Commissioners of company } \mathrm{i} \\ & : \text { in period } \mathrm{t} \\ \text { KAUDit } & : \text { Size of Audit Committee of } \\ & \text { company } \mathrm{i} \text { in period } \mathrm{t} \\ \text { BIG4it } & : \text { External Audit Big } 4 \\ & \text { companies } \mathrm{i} \text { in period } \mathrm{t} \\ \mathrm{E} & : \text { Error (error) }\end{array}$

Copyright @ 2018 AKRUAL: Jurnal Akuntansi 


\section{ANALYSIS AND DISCUSSION}

This research uses panel data and processed by eviews. To find out the most efficient method of the three equation models, Common Effects Model (CEM), Fixed Effects Model (FEM) and test each model using the panel data regression estimation method. The approach used in CEM is the Ordinary Least Square (OLS) method as its estimation. The calculation results are presented in table 1 below:

Random Effect Model (REM), it is necessary to

Table 1. Results of Common Effect Model Regression

Dependent Variable: ROA

Method: Panel Least Squares

Date: 06/12/17 Time: 12:02

Sample: 20122016

Periods included: 5

Cross-sections included: 7

Total panel (balanced) observations: 35

\begin{tabular}{lrlrr}
\hline \multicolumn{1}{c}{ Variable } & Coefficient & \multicolumn{1}{c}{ Std. Error } & \multicolumn{1}{c}{ t-Statistic } & \multicolumn{1}{c}{ Prob. } \\
\hline C & 0.0148 & 0.0097 & 1.5288 & 0.1368 \\
EII & 0.0115 & 0.0196 & 0.5861 & 0.5622 \\
BOC & -0.0031 & 0.0012 & -2.4616 & 0.0198 \\
KAUD & -0.0001 & 0.0002 & -0.8961 & 0.3773 \\
BIG4 & 0.0021 & 0.0024 & 0.8601 & 0.3965 \\
R-squared & 0.1845 & Mean dependent var & & 0.0091 \\
Adjusted R-squared & 0.0758 & S.D. dependent var & & 0.0070 \\
S.E. of regression & 0.0067 & Akaike info criterion & & -7.0404 \\
Sum squared resid & 0.0013 & Schwarz criterion & & -6.8182 \\
Log likelihood & 128.2069 & Hannan-Quinn criter. & & -6.9637 \\
F-statistic & 1.6971 & Durbin-Watson stat & & 1.6610 \\
Prob(F-statistic) & 0.1767 & & \\
\hline Source: Secondary & & &
\end{tabular}

Source: Secondary data processed with Eviews version 9

Based on CEM regression result shows constant value equal to 0,0148 with probability equal to 0,1368 . The regression equation with $R^{2}$ value of 0.1845 explains that variation of financial performance disclosure proxy by ROA is influenced by Islamic ethical identity, board size, audit committee size, and external audit is $18.45 \%$ and the rest of $81,55 \%$ is affected by another factor. Thus, the assumption using the
Common Effect model is unrealistic in determining the influence of Islamic ethical identity, the size of the board of commissioners, the size of the audit committee, and the external audit of financial performance.

Next is FEM with approach used is Ordinary Least Square (OLS) method as estimation technique. The calculation results are presented in table 2 below: 
Table 2. Regression Results Fixed Effect Model

Dependent Variable: ROA

Method: Panel Least Squares

Date: 06/12/17 Time: 12:03

Sample: 20122016

Periods included: 5

Cross-sections included: 7

Total panel (balanced) observations: 35

\begin{tabular}{|c|c|c|c|c|}
\hline Variable & Coefficient & Std. Error & t-Statistic & Prob. \\
\hline $\mathrm{C}$ & 0.0153 & 0.0159 & 0.9640 & 0.3446 \\
\hline EII & -0.0126 & 0.0231 & -0.5443 & 0.5913 \\
\hline $\mathrm{BOC}$ & 0.0024 & 0.0027 & 0.8999 & 0.3771 \\
\hline KAUD & -0.0006 & 0.0004 & -1.5269 & 0.1398 \\
\hline BIG4 & -0.0038 & 0.0048 & -0.7811 & 0.4424 \\
\hline \multicolumn{5}{|c|}{ Effects Specification } \\
\hline \multicolumn{5}{|c|}{ Cross-section fixed (dummy variables) } \\
\hline R-squared & 0.4830 & Mean dependent var & & 0.0091 \\
\hline Adjusted R-squared & 0.2677 & S.D. dependent var & & 0.0070 \\
\hline S.E. of regression & 0.0060 & Akaike info criterion & & -7.1534 \\
\hline Sum squared resid & 0.0008 & Schwarz criterion & & -6.6646 \\
\hline Log likelihood & 136.1853 & Hannan-Quinn criter & & -6.9847 \\
\hline F-statistic & 2.2430 & Durbin-Watson stat & & 1.9762 \\
\hline $\operatorname{Prob}($ F-statistic) & 0.0511 & & & \\
\hline
\end{tabular}

Source: Secondary data processed with Eviews version 9

Based on the result of FEM regression shows constant value equal to 0,0153 with probability equal to 0,3446 . The regression equation with $\mathrm{R} 2$ value of 0.4830 explains that the variation of financial performance proxy by ROA is influenced by Islamic ethical identity, board size, audit committee size, and external audit $48,30 \%$ and the rest equal to $51,70 \%$ influenced by other factors. Thus, the assumption using Fixed Effect model is more realistic in determining the influence of Islamic ethical identity, board size, audit committee size, and external audit on financial performance.

Last is REM with approach used is Generalized Least Square (GLS) method as estimation technique. The calculation results are presented in table 3 below:

Table 3. Random Effect Regression Model Results

Dependent Variable: ROA

Method: Panel EGLS (Cross-section random effects)

Date: 06/12/17 Time: 12:05

Sample: 20122016

Periods included: 5

Cross-sections included: 7

Total panel (balanced) observations: 35

Swamy and Arora estimator of component variances

\begin{tabular}{ccccc}
\hline Variable & Coefficient & Std. Error & t-Statistic & Prob. \\
\hline C & 0.0181 & 0.0110 & 1.6412 & 0.1112 \\
EII & -0.0005 & 0.0203 & -0.0247 & 0.9805 \\
BOC & -0.0018 & 0.0016 & -1.1735 & 0.2498 \\
KAUD & -0.0002 & 0.0002 & -0.9703 & 0.3397 \\
BIG4 & 0.0012 & 0.0030 & 0.4098 & 0.6848
\end{tabular}


Sunarsih, Firmansyah, Directives For Sharia Banking...

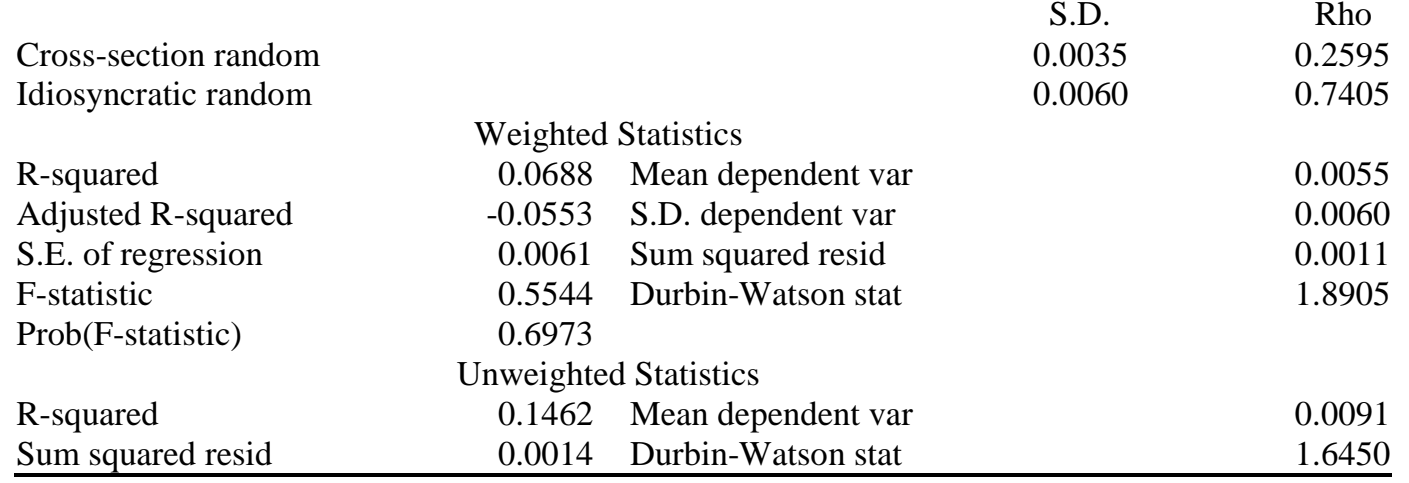

Source: Secondary data is processed with Eviews version 9

Based on REM regression result shows constant value equal to 0,0181 with probability equal to 0,1112 . The regression equation with $\mathrm{R} 2$ value of 0,0688 explains that the variation of financial performance disclosure proxyed by ROA is influenced by Islamic ethical identity, board size, audit committee size, and external audit is $6.88 \%$ and the rest of $93.12 \%$ is affected by another factor. Thus, the assumption using the Random Effect model is unrealistic in determining the influence of Islamic ethical identity, the size of the board of commissioners, the size of the audit committee, the external audit of financial performance.

To select the right regression model, chow test, hausman test and lagrange multiplier test are performed. The chow test is a test used to select the best approach between the CEM and FEM approach models in estimating panel data.

Table 4. Chow Test Results

Redundant Fixed Effects Tests

Equation: FIXED

Test cross-section fixed effects

Effects Test

Cross-section F

Statistic

d.f.

Prob.

Cross-section Chi-square

2.3104

$(6,24)$

0.0667

15.9569

6

0.0140

Cross-section fixed effects test equation:

Dependent Variable: ROA

Method: Panel Least Squares

Date: 06/12/17 Time: 12:11

Sample: 20122016

Periods included: 5

Cross-sections included: 7

Total panel (balanced) observations: 35

\begin{tabular}{crcrl}
\hline Variable & Coefficient & Std. Error & t-Statistic & Prob. \\
\hline C & 0.0148 & 0.0097 & 1.5288 & 0.1368 \\
EII & 0.0115 & 0.0196 & 0.5861 & 0.5622 \\
BOC & -0.0031 & 0.0013 & -2.4617 & 0.0198 \\
KAUD & -0.0001 & 0.0002 & -0.8961 & 0.3773 \\
BIG4 & 0.0021 & 0.0024 & 0.8601 & 0.3965 \\
R-squared & 0.1845 & Mean dependent var & & 0.0091 \\
Adjusted R-squared & 0.0758 & S.D. dependent var & & 0.0070 \\
S.E. of regression & 0.0067 & Akaike info criterion & & -7.0404 \\
Sum squared resid & 0.0013 & Schwarz criterion & & -6.8182
\end{tabular}


AKRUAL: Jurnal Akuntansi, volume 9, nomor 2, April 2018 (111-128)

Log likelihood

128.2069 Hannan-Quinn criter.

F-statistic

1.6971 Durbin-Watson stat

1.6610

Prob(F-statistic)

0.1767

Source: Secondary data processed with Eviews version 9

Test results chow shows that the

Furthermore, the hausman test is a test probability value cross section $\mathrm{F}$ amount 0,0667 used to select the best approach between REM $>0,05$, means $\mathrm{H}_{0}$ accepted. Thus, the most appropriate model in estimating regression and FEM approach model in estimating panel equations is the Common Effect Model (CEM).

Table 5. Hausman Test Results

Correlated Random Effects - Hausman Test

Equation: RANDOM

Test cross-section random effects

Test Summary

Chi-Sq. Statistic

5.9398

Chi-Sq. d.f.

Prob.

Cross-section random data.

Cross-section random effects test comparisons:

\begin{tabular}{crrrc}
\hline Variable & \multicolumn{1}{c}{ Fixed } & \multicolumn{1}{c}{ Random } & Var(Diff.) & Prob. \\
\hline EII & -0.0126 & -0.0005 & 0.0001 & 0.2725 \\
BOC & 0.0024 & -0.0018 & 0.0001 & 0.0506 \\
KAUD & -0.0006 & -0.0002 & 0.0001 & 0.2384 \\
BIG4 & -0.0038 & 0.0012 & 0.0001 & 0.1833
\end{tabular}

Cross-section random effects test equation:

Dependent Variable: ROA

Method: Panel Least Squares

Date: 06/12/17 Time: 12:16

Sample: 20122016

Periods included: 5

Cross-sections included: 7

Total panel (balanced) observations: 35

\begin{tabular}{crrrl}
\hline Variable & Coefficient & Std. Error & \multicolumn{1}{c}{ t-Statistic } & Prob. \\
\hline C & 0.0153 & 0.0159 & 0.9640 & 0.3446 \\
EII & -0.0126 & 0.0231 & -0.5443 & 0.5913 \\
BOC & 0.0024 & 0.0027 & 0.8999 & 0.3771 \\
KAUD & -0.0006 & 0.0004 & -1.5269 & 0.1398 \\
BIG4 & -0.0038 & 0.0048 & -0.7811 & 0.4424
\end{tabular}

Cross-section fixed (dummy variables)

Effects Specification

R-squared

Adjusted R-squared

S.E. of regression

Sum squared resid

Log likelihood

F-statistic

Prob(F-statistic)
0.4831 Mean dependent var $\quad 0.0091$

0.2677 S.D. dependent var

0.0060 Akaike info criterion $\quad-7.1534$

0.0008 Schwarz criterion $\quad-6.6646$

136.1853 Hannan-Quinn criter. $\quad-6.9847$

2.2430 Durbin-Watson stat 1.9762

Source: Secondary data processed with Eviews version 9 
Test result hausman shows that the probability value of cross section random is 0,2037>0,05, means $\mathrm{H}_{0}$ accepted. Thus, the most appropriate model in estimating regression equations is the Random Effect Model (REM).
The lagrange multiplier test is the test used to select the best approach between the CEM and REM approach models in estimating panel data.

Table 6. Lagrange Multiplier Test Results

\begin{tabular}{lccc}
\hline & \multicolumn{3}{c}{ Test Hypothesis } \\
\hline & Cross-section & Time & Both \\
Breusch-Pagan & 0.0054 & 0.0244 & 0.0299 \\
& $(0.9414)$ & $(0.8757)$ & $(0.8628)$ \\
\hline
\end{tabular}

Source: Secondary data is processed with Eviews version 9

The result of lagrange multiplier test shows probability value of pagan breusch cross section 0,9414>0,05, meaning H0 is accepted. Thus, the most appropriate model for estimating regression equations is the Common Effect Model (CEM).

Based on the above three tests show that by using chow test and lagrange multiplier test, it can be seen that the most appropriate result in estimating regression equation is common effect model. Thus, it can be concluded that the best model approach used to determine the influence of Islamic ethical identity disclosure, the size of the board of commissioners, the size of the audit committee, and the external audit of the financial performance projected by ROA on sharia banking companies registered in OJK 2012 to 2016 are Common Effect Model (CEM).

After determining the appropriate model to be used in panel data regression equation is Common Effect Model (CEM), it is necessary to test with classical assumption test consisting of normality test, multicolinearity test, autocorrelation test, and heteroscedasticity test.
Normality test in this test using test Jarque-Bera (J-B), with terms of value JarqueBera $(\mathrm{J}-\mathrm{B})<\chi^{2}$ tables and probability values $>$ 0,05 , then it can be said the data is normally distributed. The results of data processing shows normality test has a value Jarque-Bera (J-B) amount $6,7184<7,8147$ and a probability value of $0,3476>0,05$. So it can be concluded that the data is normally distributed. Multicollinearity test among variables can be identified by using correlation value among independent variables. If the correlation value $<0.80$ then there is no multicollinearity problem. The result of data processing shows that the correlation value between independent variables is less than 0.80 , so it can be concluded that there is no problem multikolinearitas between independent variables in the regression model. Next is the autocorrelation test carried out by the Durbin Waston (DW-Test) test. Based on the data processing results obtained Durbin Watson (DW) value of 1.6610. while the value dLsebesar 1.2221 and the upper limit value (du) of 1.7259. Thus the DW values are between $\mathrm{dl}$ 
AKRUAL: Jurnal Akuntansi, volume 9, nomor 2, April 2018 (111-128)

and $d u(d L \leq D W \leq d u)$. Based on the results of the processing, it can be concluded that there is no autocorrelation in the regression model. Heterocedasticity test was performed by glejser test. Based on the results of glejser test that the probability value of significance above the level of confidence $5 \%$. So it can be concluded that the regression model is free from heterokedastisitas.

Table 7. Determination Coefficient Test (Test $\mathrm{R}^{2}$ )

\begin{tabular}{|c|}
\hline \\
\hline $\begin{array}{l}\text { Source: Secondary data is processed with Eviews } \\
\text { version } 9 \\
\text { In this research, the determination } \\
\text { coefficient test is done to measure the } \\
\text { independent variable that is the ethical identity } \\
\text { of Islam and CG and the dependent variable is } \\
\text { the financial performance. Based on table } 1 \\
\text { shows that the coefficient of determination } \\
\text { obtained value of adjusted R2 of } 0.0758 \\
\text { (7.58\%). This means that } 7.58 \% \text { of financial } \\
\text { performance variables projected with ROA can } \\
\text { be influenced by Islamic ethical identity, board } \\
\text { size, audit committee size, and external audit. } \\
\text { While } 92.42 \% \text { is explained by other factors not }\end{array}$ \\
\hline
\end{tabular}

Hypothesis testing in this research is done by using the panel regression analysis model. In this study used hypothesis testing by means of simultaneous test ( $\mathrm{F}$ test) and test per variable ( $\mathrm{t}$ test). The simultaneous test (F test) is conducted to test whether all independent variables together in the regression equation model have an influence on the dependent variable. Results of data processing with an $\mathrm{F}$ test seen in table 2 and shows probability value of 0.1767 greater than 0.05 significance $(0.1767>0.05)$. This means that Islamic ethical identity variables, board of commissioner size, audit committee size, and external audit do not simultaneously affect the financial performance peroxide by ROA.

Table 8. Test of Simultaneous Test F

\begin{tabular}{l}
\hline F-statistic \\
\hline Prob.(F-statistic) \\
Source: Secondarry data is processed with Eviews \\
version 9 \\
The t test aims to determine whether the \\
ndependent variables are partially significant to \\
which of the independent variables affect the \\
financial performance of sharia banking in \\
Indonesia. The result of t test can be shown in \\
able 3.
\end{tabular}
table 3.

Table 9. Partial Test (test)

\begin{tabular}{ccccc}
\hline Variable & Coefficient & Std. Error & t-Statistic & Prob. \\
\hline C & 0.0148 & 0.0097 & 1.5288 & 0.1368 \\
EII & 0.0115 & 0.0196 & 0.5861 & 0.5622 \\
BOC & -0.0031 & 0.0012 & -2.4616 & 0.0198 \\
KAUD & -0.0001 & 0.0002 & -0.8961 & 0.3773 \\
BIG4 & 0.0021 & 0.0024 & 0.8601 & 0.3965 \\
\hline
\end{tabular}

Source: Secondary data is processed with Eviews version 9 
Based on table 3 shows that Islamic ethical identity variable (EII) has a probability value of 0.5622 greater than the significance of $0.05(0.5622>0.05)$. So it can be concluded that the variable of Islamic ethical identity partially has no effect on the financial performance of sharia banking. Thus, the first hypothesis which states that the identity of Islamic ethics affect the financial performance is rejected. Furthermore, the variable size of the board of commissioners has a probability value of 0.0198 is smaller than the significance of $0.05(0.0198<0.05)$. So it can be concluded that the variable size of the board of commissioners partially affects the financial performance. Thus, the second hypothesis concerning the board of commissioners influence the financial performance is accepted.

The audit committee variable has a probability value of 0.3773 greater than the significance of $0.05(0.3773>0.05)$. So it can be concluded that the audit committee size variable partially has no effect on the financial performance of sharia banking. Thus, the third hypothesis of the audit committee affect the financial performance is rejected. Last is the external audit variable has a probability value of 0.3965 is greater than the significance of 0.05 $(0.3965>0.05)$. So it can be concluded that the external audit variable partially has no effect on the financial performance of sharia banking. Thus, the fourth hypothesis concerning external audit affect the financial performance is rejected. Based on Table 3, the panel regression equation model is as follows:

\section{$\mathrm{ROA}_{\text {it }}=0,0148+0,0115 \mathrm{EII}_{\mathrm{it}}-0,0031 \mathrm{BOC}_{\text {it }}-$ $0,0001 \mathrm{KAUD}_{\text {it }}+0,0021$ Big $4_{\text {it }}+\mathrm{e}$}

Based on table 3 showed that the first hypothesis that the variable of Islamic ethical identity has an effect on the financial performance of sharia banking is rejected. Rejection of the first hypothesis because there are various variations in terms of way of view of investors to measure the performance of the company, there is a view that the company's performance measure is measured only limited to the financial only company profit. There is also a comprehensive view of the company's performance measures, viewed from financial and non-financial. This perspective will ultimately affect investors in assessing the company. Though should the Muslim investors have a comprehensive view of the performance measures of financial and non-financial nature. So that Muslim investors will see the company's operations not only of a financial nature, but the identity of Islamic ethics as a feature of Islamic banking must be considered as well. Islamic identity ethics actually reflects information related to the identity of Islamic business ethics that differentiates sharia banking with conventional banks, as well as the conformity of sharia banking system and operations with the principles of sharia (Fauziyah \& Siswantoro, 2016).

The results of this study contrasted with Sukardi \& Wijaya (2013); (Berman, 1999; Hillman and Keim, 2001; in (Fauziyah \& Siswantoro, 2016) stating that a strong ethical identity will achieve greater stakeholder 
satisfaction, and have an effect on financial performance. Furthermore, the second hypothesis stated that the size of the board of commissioner affect the financial performance of Islamic banking is accepted. The results of this study indicate that the board of commissioners has performed its function, thus giving a positive impact on improving the company's financial performance. The acceptance of the second hypothesis proves that the board of commissioners has run the role well that is doing good supervision and exercise caution for the interests of the company in accordance with company goals. Another argument for the acceptance of the second hypothesis is that the strategic board position is occupied by people who have a high loyalty to the company, so that it has no personal interest in the company that can lead to losses and always give input to the directors to prevent the occurrence of losses. The better the performance of the board of commissioners of a company, it will affect the improvement of company performance.

The results of this study support research conducted by Sulistyowati \& Fidiana (2017) which states that the size of the board of commissioners is an important element affecting financial performance and contrary to the results of research conducted by Nopiani et al., (2015); Darwis (2009) which states that it is difficult to determine how optimal the size of the board of commissioners To improve the performance of the company. According to Nopiani et al.,
(2015) stated that the number of members of a board of commissioners must also be tailored to the needs and complexities of the company's activities. So that does not guarantee that the number of boards will affect the performance of the company.

The third hypothesis which states that audit committee variables affect the financial performance of sharia banking is rejected. This shows that audit committees in the company are not performing their duties properly, which is to help the commissioners to improve the quality of financial statements and increase the effectiveness of internal and external audit. The rejection of this third hypothesis, it is possible that the existence of an audit committee cannot guarantee transparency in financial statements, justice for all stakeholders, and disclosure of information by management. Based on the results of the research show that audit committee cannot improve company performance. The results of this study support research conducted by Sulistyowati \& Fidiana (2017); Merawati \& Hatta (2014) that audit committee has no significant effect on financial performance and contrary to result of research conducted by (Masjid \& Cahyono, 2015) stated that audit committee have positive effect to company performance. It is proven that the audit committee is responsible for overseeing the financial statements, overseeing external audits, and observing internal control systems (including internal auditing) so as to reduce the opportunistic nature of management that cheats

Copyright @ 2018 AKRUAL: Jurnal Akuntansi 
in the form of earnings management by overseeing the financial statements and supervising external audits.

The last hypothesis states that the external audit variables affect the financial performance of Islamic banking is rejected. This indicates that the existence of an external audit company is not proven to improve the company's financial performance. The results of this study deviate from the theory that external auditors have an important role in creating corporate value and the implementation of good corporate governance because it is considered more independent than the internal audit (Merawati \& Hatta, 2014). The results of this fourth hypothesis test do not support research conducted Merawati \& Hatta (2014); Christiani \& Nugrahanti (2014) which states external audit has a positive and significant impact on ROA. This means that firms audited by KAP big 4 have higher ROA values than firms audited by non-big KAP 4. Sari (2010) also stated the same thing that external audit (big 4) has a significant positive effect on the company's financial performance. This means, the measure of company performance as measured by the external auditor (big 4) is higher than the company audited by external audit non big 4 .

\section{CONCLUSIONS}

The result of the research concludes that sharia banking that reveal Islamic ethical identity has no effect to financial performance. This is possible because investors have different views about the size of the company's financial performance, there are investors who have the view that the company's performance measures are only reflected in its finances, but there are also investors who have a comprehensive view of financial size that is viewed from the financial side and non-financial. The results of this study are inconsistent with Sukardi \& Wijaya (2013); Berman, 1999; Hillman and Keim, 2001; in Fauziyah \& Siswantoro (2016) proving that a strong ethical identity will achieve greater stakeholder satisfaction, and have an effect on financial performance. Hereinafter is variable size of board of commissioner having an effect on to financial performance of syariah banking. This proves that the board of commissioners in sharia banking has run the performan well with the supervision and conduct caution in accordance with the objectives of sharia banking. The better the performance of the board of commissioners of a company, it will influence the improvement of company performance. The results of this study are consistent with research conducted by Sulistyowati \& Fidiana (2017) which states that the size of the board of commissioners is an important element that affects financial performance. While the third variable that the audit committee does not affect the financial performance of banks. This proves that audit committees residing in banks are not running cannot perform their role to reduce the opportunistic nature of management. The results of this study are consistent with research Sulistyowati \& Fidiana (2017); Merawati \& Hatta (2014) that audit committee has no significant effect on financial performance. Last 
is the external audit variable has no effect on the financial performance of sharia banking. This shows that the existence of an external audit company cannot guarantee the audit process goes according to the procedure so it is considered not able to provide high quality audits.

\section{REFERENCES}

Anthony, \& Govindarajan. (2005). Management Control System. Jakarta: Salemba Empat.

Armadi, \& Anggraeni, M. D. (2010). Pengaruh Pengungkapan Sukarela pada Cost of Equity Capital dengan Asimetri Informasi sebagai Intervening Variable. Trikonomika, 9(1), 62-71.

Beiner, S., Dorbetz, W., Schmid, F., \& Zimmermann, H. (2003). Is Board Size an Independent Corporate Governance Mechanism ? Finrisk, 5(April), 1-34. DOI: https://doi.org/10.1111/j.00235962.2004.0 0257.x

Berrone, P., Surroca, J., \& Tribó, J. A. (2007). Corporate ethical identity as a determinant of firm performance: A test of the mediating role of stakeholder satisfaction. Journal of Business Ethics, 76(1), 35-53. DOI:https://doi.org/10.1007/s10551-0069276-1

Boove, L. C., \& Thill, J. V. (2002). Komunikasi Bisnis (Edisi ke e). Jakarta: PT Prenhalindo.

Christiani, I., \& Nugrahanti, Y. W. (2014). Pengaruh Kualitas Audit Terhadap Manajemen Laba. Jurnal Akuntansi Dan Keuangan, 16(1), 52-62. DOI: https://doi.org/10.974 4/jak.16.1.52-62

Darwis, H. (2009). Corporate Governance terhadap Kinerja Perusahaan. Jurnal Keuangan Dan Perbankan, 1(3), 418.

Effendi, M. A. (2016). The Power of Good Corporate Governance: Teori dan Implementasi (Kedua). Jakarta: Salemba Empat.

Fahmi, I. (2014). Analisis Laporan Keuangan. Bandung: Penerbit Alfabeta.
Fauziyah, Y., \& Siswantoro, D. (2016). Analisis Pengungkapan Identitas Etika Islam dan Kinerja Keuangan Perbankan Syariah di Indonesia. In Simposium Nasional Akuntansi XIX (pp. 1-19). Lampung.

Haniffa, R., \& Hudaib, M. (2007). Exploring the ethical identity of Islamic Banks via communication in annual reports. Journal of Business Ethics, 76(1), 97-116. DOI:https://doi.org/10.1007/s10551-0069272-5

Masjid, M. T. A., \& Cahyono, Y. T. (2015). Pengaruh Good Corporate Governance terhadap Kinerja Perusahaan Manufaktur. In Seminar Nasional dan The 2nd Call for Syariah Paper.

Merawati, E. E., \& Hatta, I. H. (2014). Pengaruh Pengawasan Komite Audit, Audit Internal, Audit Eksternal terhadap Kesehatan Keuangan Perusahaan dan Dampaknya terhadap Profitabilitas. Jurnal Akuntansi, $X V I I I(3), \quad 335-349 . \quad$ DOI: https://doi.org/10.24912/ja. v18i3.269

Nopiani, K. D., Sulindawati, L. G. E., \& Sujana, E. (2015). Pengaruh Mekanisme Good Corporate Governance Terhadap Kinerja Keuangan Bank Perkreditan Rakyat Di Bali. E-Journal Universitas Pendidikan Ganesha, 3(1).

Purwanto, D. (2006). Komunikasi Bisnis (Ketiga). Jakarta: Erlangga.

Riel, C. B. M. Van, \& Balmer, J. M. T. (1997). Corporate identity: the concept, its measurement and management. European Journal of Marketing, 31(5), 340-355. DOI: https://doi.org/10.1108/eb060635

Sekaran, U., \& Bougie, R. (2010). Research Methods For Business: A Skill Building Approach. John Wiley \& Sons, Ins.

Setyorini, D. (2007). Laporan tahunan VS Ringkasan Laporan Tahunan: antara kemampuan dibaca dan dipahami. Jurnal Ekonomi \& Pendidikan, 4(1), 34-41.

Sukardi, B., \& Wijaya, T. (2013). Corporate Ethical Identity Perbankan Syariah di Indonesia. Tsaqafah Jurnal Peradaban Islam, 9(2). DOI: https://doi.org/10.21111/ tsaqafah.v9i2.56 
Sulistyowati, \& Fidiana. (2017). Pengaruh Good Corporate Governance Terhadap Kinerja Keuangan Perusahaan. Jurnal Ilmu Dan Riset Akuntansi, 6(1), 121-137.

Wibowo. (2013). Perilaku Dalam Organisasi. Jakarta: PT Rajagrafindo Persada.

Widayati, M. F. (2013). Pengaruh Dewan Direksi, Komisaris independen, Komite Audit, Kepemilikan Manajerial dan kepemilikan Institusiaonal terhadap Kinerja Keuangan. Jurnal Ilmu Manajemen, 1(1), 234-249.

Yaya, R., Martawireja, A. E., \& Abdurahim, A. (2016). Akuntansi Perbankan Syariah Teori dan Praktik Kontemporer (Edisii Ked). Jakarta: Penerbit Salemba Empat.

Zaki, A., Sholihin, M., \& Barokah, Z. (2014). The association of Islamic bank ethical identity and financial performance: evidence from Asia, (1), 97-110. DOI: https://doi.org/ 10.1007/s13520-014-00347 